\title{
Post-harvest Drying of Fresh Rice Grain and Its Effects on Deterioration of Lipids during Storage
}

\author{
Hiroyuki Ohta, ${ }^{*}$ Shigeo Aibara, ${ }^{* *}$ Honami Yamashita, \\ Futoshi Sekiyama and Yuhei Morita \\ Research Institute for Food Science, Kyoto University, \\ Uji, Kyoto 611, Japan \\ Received October 23, 1989
}

\begin{abstract}
Fresh rice grains were dried after harvest by three different drying methods (natural, dehumidified-air, and heated-air drying), and changes in the lipid contents and lipid metabolizing enzyme activities were investigated after storage at $4 \mathrm{C}$ and ambient temperature. The contents of triacylglycerols and phospholipids in the grains decreased after 15 months storage at ambient temperature. In the case of heated-air drying at $50^{\circ} \mathrm{C}$, the decrease was the largest. However, marked changes were not found in the grains stored at $4 . \mathrm{C}$. Electron micrographs of the spherosome particles showed that some deformation and fusion occurred in the grains with the heated-air drying at $50^{\circ} \mathrm{C}$ after 6 and 12 months of storage. However, such changes in spherosomes were distinctly suppressed in the grains dried by the dehumidified-air dryer at $30^{\circ} \mathrm{C}$. It is noted from this evidence that the conditions of post-harvest drying of fresh rice grains markedly influence the deterioration of rice grains in storage.
\end{abstract}

The control of post-harvest treatments of rice grains is important for preservation. After harvest, rice grains must be dried to a safe storage level of water content to suppress respiration, mold growth, and the generation of microorganisms. Heated-air drying is a conventional process for post-harvest treatments, in place of natural drying in the field. However, high temperature drying is not appropriate because it damages the viability or physical properties of grains such as kernel breakage or a decrease of good flavor. Thus, many efforts has been made to establish alternative drying methods for maintaining the quality of fresh rice grains.

Geddes ${ }^{11}$ indicated that water content is the most important factor affecting the behavior of grain in storage. In fact, insufficient drying causes ethanol accumulation in rice grains, since anaerobic respiration is very high in fresh rice grains. ${ }^{2 y}$ We have already reported that the storage condition of rice grains significantly influences the rice quality. ${ }^{3)}$ This paper de- scribes some drying methods for fresh rice grains and their effects on the deterioration of the lipids during storage.

\section{Materials and Methods}

Rice. Three kinds of rice grains, "Nipponbare," "Asominori," and "Oozora," were used in this study. Nipponbare was harvested in Shiga and Kyoto in 1984, and in Mie and Kyoto in 1985. Asominori was harvested in Kyoto in 1984, and Oozora in Mie in 1984.

Chemicals. Choline oxidase and peroxidase were obtained from Toyobo, Osaka. Boron trifuoride-methanol was from Tokyo Kasei Kogyo Co., Tokyo. Thin-layer chromatography (TLC) plates were from Merck, Darmstadt. Egg yolk phosphatidylcholine was from Sigma Chemical Co., St Louis. Other chemicals were commercial products of high purity.

Dehumidified-air dryer. The dehumidified-air dryer was designed according to the principles shown in Fig. 1. The dryer was manufactured for trial by Daikin Co. at our request. This dryer can continuously ventilate air the temperature and relative humidity of which are controlled.

* Present address: National Institute for Basic Biology, Myodaiji, Okazaki 444, Japan.

** To whom correspondence and reprint requests should be addressed.

Abbreviations: LOX, lipoxygenase; PL-D, phospholipase D; RH, relative humidity. 


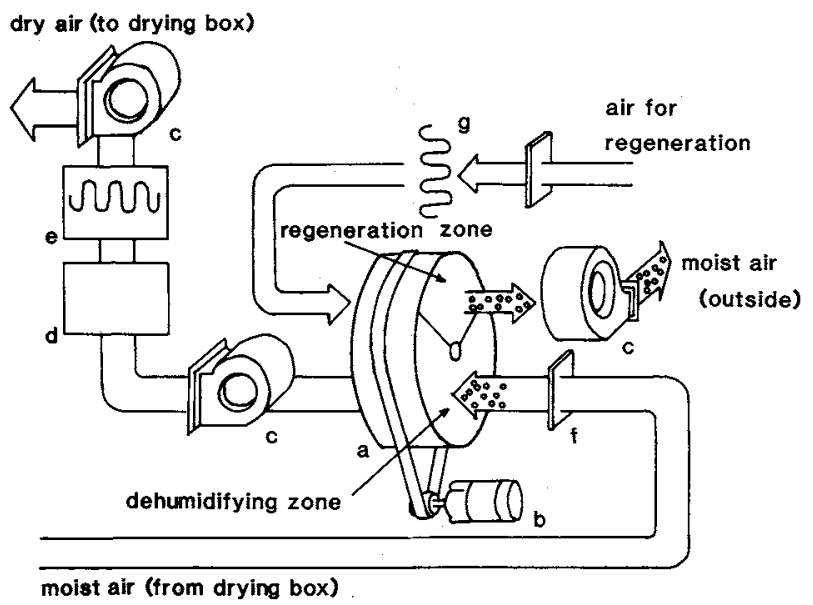

Fig. 1. The Principles of the Dehumidified-air Drier.

$\mathrm{a}$, honeycomb rotor; $\mathrm{b}$, motor; $\mathrm{c}$, fan; $\mathrm{d}$, cooler; e, humidifier; $\mathrm{f}$, filter; $\mathrm{g}$, heater. The dehumidifier has a honeycomb rotor on which activated charcoal- $\mathrm{LiCl}$ granules are applied, and the charcoal is activated in the regenerating zone continuously after dehumidifying the moist air in the drying box. This dehumidifier is coupled with a refrigerator to control the temperature of the dehumidified air.

The capacity of the drier: maximum air-flow, $5 \mathrm{~m}^{3} / \mathrm{min}$; temperature range, $5-40^{\circ} \mathrm{C}$; relative humidity range, $5-40 \%$, maximum capacity of the drying box, $3 \mathrm{~kg}$. It is equipped with recorders of the temperature and relative humidity.

Drying of the grains. Rice grains were dried by the following 3 methods to a safe storage level of water content $(15 \%)$. Dehumidified-air drying: $2 \mathrm{~kg}$ of the fresh rice grains were spread about $3 \mathrm{~cm}$ thick over a stainless steel net $(30 \times 30 \mathrm{~cm})$. Then, the dehumidified air was ventilated at a flow rate of $5 \mathrm{~m}^{3} / \mathrm{min}$. Natural drying: grains were left in ventilated shade without temperature control. Heated-air drying: grains were dried by a continuous flow of heated air in a oven at $50^{\circ} \mathrm{C}$ for $2 \mathrm{hr}$.

Water content. Water content was measured gravimetrically. Duplicated samples of about $10 \mathrm{~g}$ of rice grains were dried for $2 \mathrm{hr}$ at $110^{\circ} \mathrm{C}$ and then weighed. This procedure was repeated several times until the sample weight became constant. The mean values were calculated for water content. The conventional water content of the dried grains was estimated by a Kett moisture meter (PB-1K).

Estimation of kernel breakage. The breakage ratio of the dried grains was estimated by soft X-ray. X-ray pictures of the rough rices ( 300 to 600 grains) dried under various conditions were taken and the number of cracked grains was counted. Breakage ratio of dried grains was defined as the ratio of cracked grains to total grains.

Germination. A hundred rice grains were placed on a circular sheet of filter paper in an 15-cm Petri dish and steeped in water at $4^{\circ} \mathrm{C}$ overnight before starting the germination test. The test was done at $30^{\circ} \mathrm{C}$ in the dark and the germinated grains were counted after 5 days of incubation.

Extraction of the lipids from rice bran. Rice bran lipids were extracted by a modification of the method of Aibara et $a l .{ }^{3)}$ One hundred and fifty $g$ of brown rice was ground with an experimental grinder for $25 \mathrm{sec}$ to obtain rice bran. The lipids were extracted from the bran 3 times with $30 \mathrm{ml}$ of chloroform-methanol $(2: 1, \mathrm{v} / \mathrm{v})$ at $30^{\circ} \mathrm{C}$ for $30 \mathrm{~min}$. The extracts were combined, concentrated on a rotary evaporator, and filled up to $30 \mathrm{ml}$ with the chloroformmethanol. The extract was washed 3 times with 0.2 volume of $0.1 \mathrm{M}$ potassium chloride to remove water-soluble materials and the interfacial fluff formed during these washes. Separation of the extracted lipids and measurement of lipid content were described previously. ${ }^{3}$;

Electron micrograph of spherosome particles. A rice grain was cut into pieces with a razor blade to isolate the aleurone cells which contain the spherosome particles. Then, the pieces of the grain were fixed with $3 \%$ glutaraldehyde in $50 \mathrm{~mm}$ phosphate buffer, $\mathrm{pH} 7.0$, containing $250 \mathrm{~mm}$ sucrose. After washing, the pieces were fixed in $1 \%$ osmium tetroxide in the phosphate buffer at $0^{\circ} \mathrm{C}$ for $2 \mathrm{hr}$, and then dehydrated in a gradient series of ethanol and propylene oxide. ${ }^{4-6)}$ The samples were embedded in epoxy resin by the method of Tanaka et al ${ }^{7)}$ The embedded samples were cut with a glass knife on the outer layers of the grain by an ultramicrotome. The sections were observed with a Hitachi transmission electron microscope (TEM) $\mathrm{H}-700$. 
Preparation of crude enzyme. Fifty $\mathrm{g}$ of husked rice grains after drying and storage under various conditions were ground for $25 \mathrm{sec}$. The obtained embryo and bran fraction was macerated with mortar and pestle for $5 \mathrm{~min}$ and the enzymes were extracted with $50 \mathrm{~mm}$ Tris- $\mathrm{HCl}, \mathrm{pH}$ 7.0 , for $1 \mathrm{hr}$ at $4^{\circ} \mathrm{C}$. The extract was centrifuged at $13,000 \times g$ for $10 \mathrm{~min}$ and the supernatant was assayed for the enzyme activities.

Assay of enzyme activities. Phospholipase D (PL-D) activity was assayed at $\mathrm{pH} 7.2$ by a modification of the method of Imamura and Horiuti. ${ }^{8}$ The reaction was started by adding $0.05 \mathrm{ml}$ of the enzyme solution to $0.450 \mathrm{ml}$ of a reaction mixture composed of $0.2 \mathrm{ml}$ of egg yolk phosphatidylcholine $(4 \mathrm{mg} / \mathrm{ml}), 0.05 \mathrm{ml}$ of $0.4 \mathrm{M}$ Tris$\mathrm{HCl}, \mathrm{pH} 7.2,0.04 \mathrm{ml}$ of $50 \mathrm{~mm}$ sodium deoxycholate, $0.025 \mathrm{ml}$ of $0.1 \mathrm{M} \mathrm{CaCl}_{2}$, and $0.135 \mathrm{ml}$ of water. The reaction mixture was left for $10 \mathrm{~min}$ at $37^{\circ} \mathrm{C}$ and the reaction was stopped by adding $0.2 \mathrm{ml}$ of $50 \mathrm{~mm}$ EDTA in I $\mathrm{M}$ Tris- $\mathrm{HCl}, \mathrm{pH} 8.0$. After addition of $0.3 \mathrm{ml}$ of the solution containing 1.5 units of choline oxidase, 0.2 units of peroxidase, $1.5 \mu \mathrm{mol}$ of 4-aminoantipyrine, and $2.1 \mu \mathrm{mol}$ of phenol, buffered with $10 \mathrm{~mm}$ Tris- $\mathrm{HCl}, \mathrm{pH} 8.0$, to the reaction mixture, the mixture was further incubated for $30 \mathrm{~min}$ at $37^{\circ} \mathrm{C}$. The reaction was stopped by adding $1 \mathrm{ml}$ of $1 \%(\mathrm{w} / \mathrm{v})$ Triton $\mathrm{X}-100$ solution. The amount of choline liberated was read from a calibration curve.

Lipoxygenase (LOX) activity was assayed by the conditions reported by Ohta et al. ${ }^{10}$

\section{Results}

Effects of temperature and relative humidity on drying time by dehumidified-air dryer

Fresh rice grains were dried by three different drying methods (natural, dehumidifiedair, and heated-air drying). Figure 2 shows the dependence of drying time on temperature and relative humidity $(\mathrm{RH})$ of the drying air with regard to the post-harvest drying of fresh rice grains. At $25^{\circ} \mathrm{C}$ and $\mathrm{RH} 20 \%$, it took $10 \mathrm{hr}$ to lower the water content $(23.3 \%)$ of fresh rice grains (Nipponbare) to $15 \%$, which is the safe storage level of rice grains. It was possible to accomplish drying for 7.5 or $4 \mathrm{hr}$ with elevating the drying temperature to 30 or $40^{\circ} \mathrm{C}$, respectively, at the same $\mathrm{RH}$. In the case of RH $5 \%$ at drying temperature of $25^{\circ} \mathrm{C}$, the drying time could be reduced to $7 \mathrm{hr}$. Furthermore, it was attained within $14 \mathrm{hr}$ even at $15^{\circ} \mathrm{C}$, while it took only $2.5 \mathrm{hr}$ by heated-air drying at $50^{\circ} \mathrm{C}$.

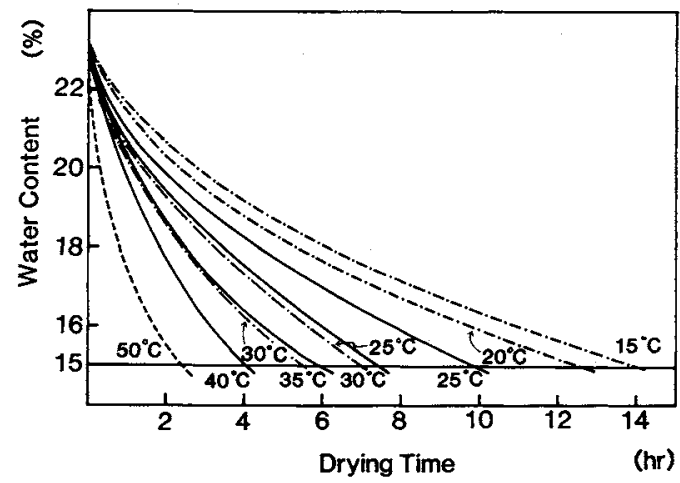

Fig. 2. Effects of Temperature on Drying Time of Fresh Rice Grains.

Two kg of fresh rice grains (Nipponbare) were spread over the mesh plates in the drying box and dried as described in Materials and Methods. At 1 -hr intervals, about $2 \mathrm{~g}$ of the dried grains were picked up, and the water content was measured. --.--, heated-air Crying at $50^{\circ} \mathrm{C}$; ---- , RH $5 \%$.

Table I. Breakage Ratio of Rice (Nipponbare) BY DRYING

$(\%)$

\begin{tabular}{lrrr}
\hline \multirow{2}{*}{ Temp. } & \multicolumn{3}{c}{ Relative humidity } \\
\cline { 2 - 4 } & $5 \%$ & $10 \%$ & $20 \%$ \\
\hline $20^{\circ} \mathrm{C}$ & 3.3 & & \\
$25^{\circ} \mathrm{C}$ & 4.1 & & \\
$30^{\circ} \mathrm{C}$ & 3.5 & 5.5 & 3.9 \\
$35^{\circ} \mathrm{C}$ & 4.2 & & 6.4 \\
$40^{\circ} \mathrm{C}$ & 14.9 & & 14.8 \\
\hline Natural drying & & & 1.6 \\
\hline Drying at $50^{\circ} \mathrm{C}$ & & & 23.5 \\
\hline
\end{tabular}

\section{Kernel breakage and germination rate of the dried grains}

The three drying methods were evaluated by the kernel breakage ratio and the germination rate. When the grains were dried by the dehumidified-air dryer below $40^{\circ} \mathrm{C}$, the breakage ratio was low, although slightly higher than the natural drying (Table I). In the case of the heated-air drying at $50^{\circ} \mathrm{C}$, however, it increased to $23.5 \%$. The humidity of the drying air was not responsible for the breakage susceptibility of rice grains under the experimental conditions, although it reduced the drying 
Table II. Germination Rate of the Dried Grains $(\%)$

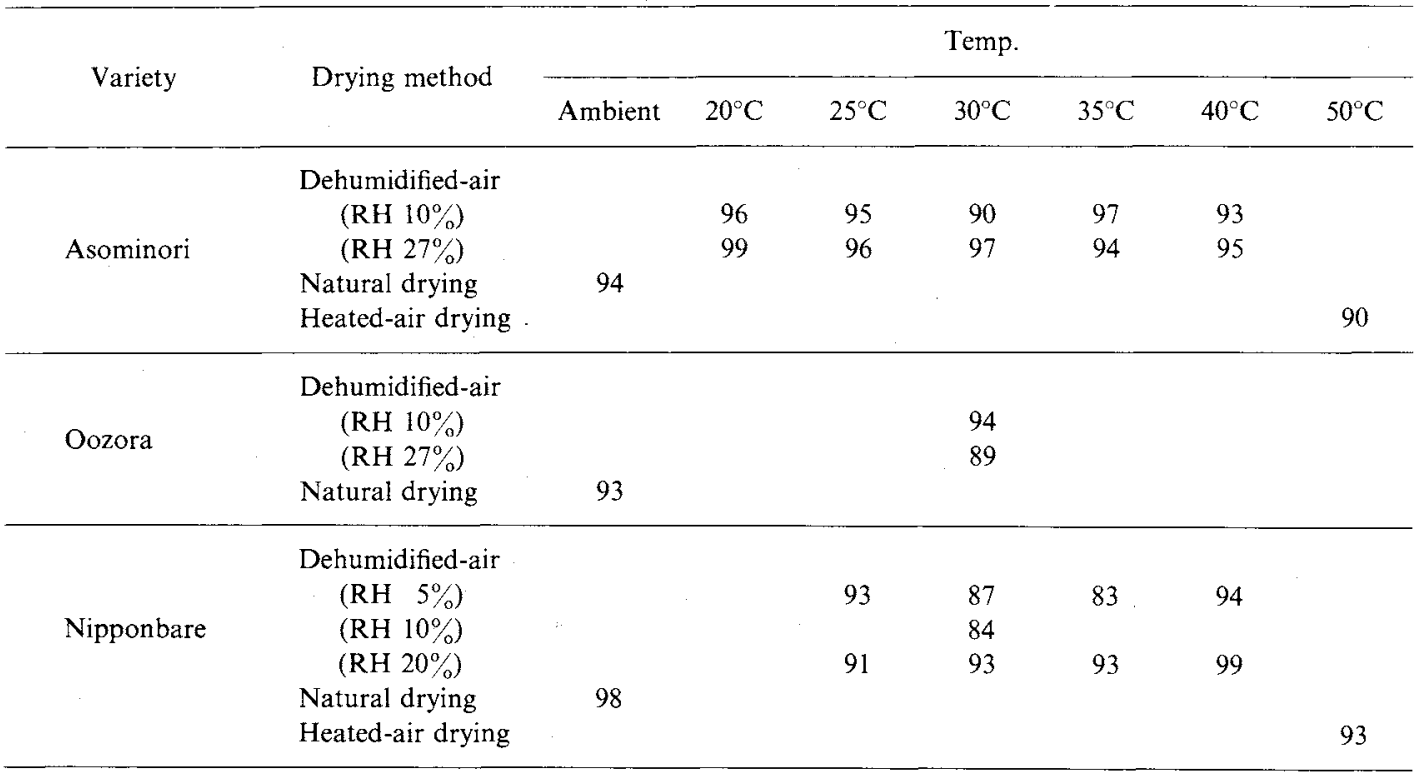

Table III. Changes in Rice Bran Lipids After 15 Months of Storage (g/100 g dry wt.)

\begin{tabular}{|c|c|c|c|c|c|c|c|}
\hline \multirow{2}{*}{$\begin{array}{l}\text { Storage } \\
\text { Drying }\end{array}$} & \multirow{2}{*}{$\frac{\text { Before storage }}{\text { Natural }}$} & \multicolumn{3}{|c|}{ Ambient temp. } & \multicolumn{3}{|c|}{$4^{\circ} \mathrm{C}$} \\
\hline & & Natural & $\begin{array}{c}30^{\circ} \mathrm{C} \\
\mathrm{RH} 5 \%\end{array}$ & $50^{\circ} \mathrm{C}$ & Natural & $\begin{array}{c}30^{\circ} \mathrm{C} \\
\mathrm{RH} 5 \%\end{array}$ & $50^{\circ} \mathrm{C}$ \\
\hline Extracted lipids & 20.5 & 19.8 & 19.4 & 19.9 & 19.9 & 19.8 & 19.3 \\
\hline Triacylglycerol & 18.3 & 16.9 & 16.0 & 15.0 & 17.8 & 17.5 & 17.9 \\
\hline Phospholipids & 0.74 & 0.64 & 0.63 & 0.57 & 0.74 & 0.72 & 0.74 \\
\hline Free fatty acids & 0.12 & 0.35 & 0.37 & 0.41 & 0.14 & 0.19 & 0.13 \\
\hline
\end{tabular}

time. The breakage susceptibility of the rice grains related to the drying temperature.

The germination rate of the dried grains was investigated as a viability index. The grains just after drying showed high germination rates regardless of the drying conditions (Table II). A few contaminating immature grains lowered the germination rates, but a high drying temperature did not cause a failure of germination ability just after drying.

\section{Change in rice bran lipids}

Table III shows the deteriorative changes in the bran lipids of the rough rice treated by the three different drying methods and stored for
15 months. In the low temperature storage at $4^{\circ} \mathrm{C}$, small amounts of loss occurred in triacylglycerols, the degree of which was not clearly distinguished among the three kinds of the drying methods. However, marked differences were observed in the ambient temperature storage for 15 months. In every drying condition, triacylglycerols decreased with the increase of free fatty acids. In the case of the natural drying and dehumidified-air drying at $30{ }^{\circ} \mathrm{C}$ and $\mathrm{RH} 5 \%$, the decrease of triacylglycerols was suppressed compared to heated-air drying at $50^{\circ} \mathrm{C}$. In spite of lowering the amounts of triacylglycerols, almost the same amounts of the extracted lipids were detected in all three 
kinds of dried grains. The result suggests that a partial degradation of triacylglycerols into mono- and di-acylglycerols occurred in the stored grains.

The decrease in phospholipids contents showed an inclination to that of the triacylglycerols (Table III). With regard to changes in phospholipid species, phosphatidic acid (PA) increased with a decrease in phosphatidylcholine (PC), lysophosphatidylcholine (LPC), and phosphatidylethanolamine (PE) regardless of the drying methods after 15 months of storage at ambient temperature (Fig. 3). Particularly, LPC was not detected after 15
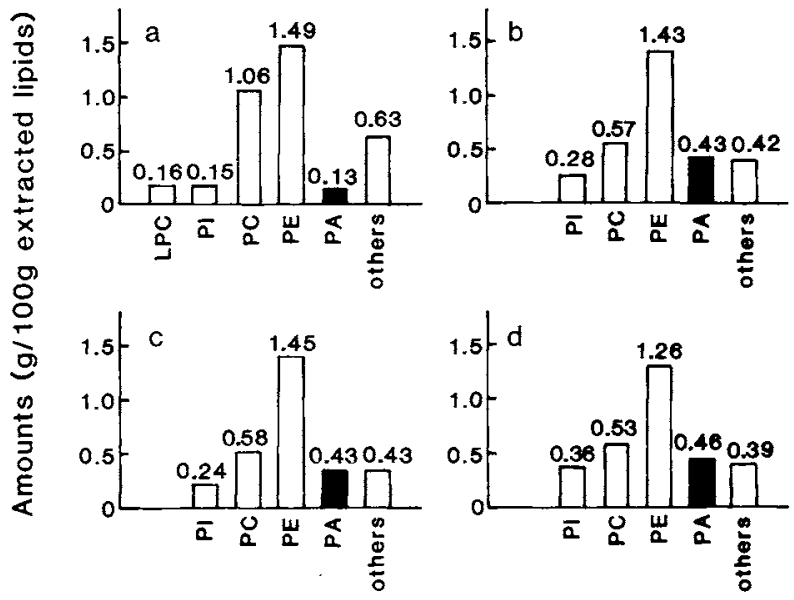

Fig. 3. Changes in the Composition of Phospholipids after 15 Months of Storage at Ambient Temperature. Phospholipid species were separated and measured as described in our previous paper. ${ }^{3)}$ a, before storage; $b$, natural drying; c, dehumidified-air drying $\left(30^{\circ} \mathrm{C}, \mathrm{RH} 5 \%\right)$ d, heated-air drying. LPC, lysophosphatidylcholine; PI, phosphatidylinositol; PC, phosphatidylcholine; PE, phosphatidylethanolamine; PA, phosphatidic acid.

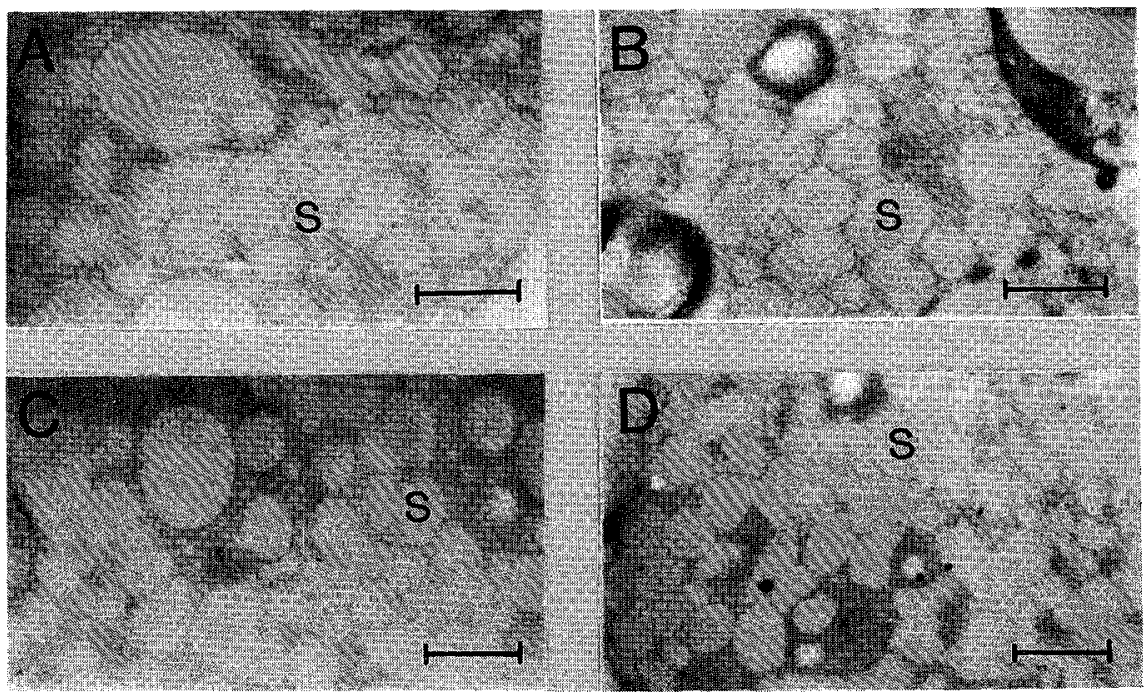

Fig. 4. Transmission Electron Micrographs of Rice Spherosome Particles after 6 and 12 Months of Storage. $\mathrm{A}$, dehumidified-air drying $\left(30^{\circ} \mathrm{C}, \mathrm{RH} 10 \%\right)$ after 6 months of storage; $\mathrm{B}$, heated-air drying $\left(50^{\circ} \mathrm{C}\right)$ after 6 months of storage; $\mathrm{C}$, dehumidified-air drying $\left(30^{\circ} \mathrm{C}, \mathrm{RH} 10 \%\right)$ after 12 months of storage; $\mathrm{D}$, heated-air drying $\left(50^{\circ} \mathrm{C}\right)$ after 12 months of storage. (S, spherosome. Bar means $2 \mu \mathrm{m}$.) 
months of storage in spite of the presence before storage of the similar amounts to phosphatidylinositol (PI). However, the increase in PA was not as high as the decrease in PC, PE, and LPC. It indicates that further decomposition of phospholipids also occurred during storage. Especially, in the case of heated-air drying at $50^{\circ} \mathrm{C}, \mathrm{PE}$ decreased profoundly compared with the natural or dehumidified-air drying methods. This suggests that degradation of the spherosome membrane, which consists of phospholipids, was more accelerated, so that triacylglycerols stored in the spherosome were easily decomposed in the grains after heated-air drying at $50^{\circ} \mathrm{C}$.

\section{Electron micrographs of spherosome particles}

Transmission electron micrographs of spherosome particles of rice grains are presented in Fig. 4. The spherosomes of the rice grain are small isomorphus granules, which exist in the aleurone cells and accumulate neutral lipids, i.e., mainly triacylglycerols. No difference in the form of the spherosome particles of the three kinds of dried grains was observed just after as well as before the drying processes (data not shown). After 6 and 12 months of storage at ambient temperature, however, considerable deformation and fusion of spherosome particles occurred in the grains dried by heated air at $50^{\circ} \mathrm{C}$, while significant changes except for a slight deformation were scarcely observed in the grains dried by the dehumidified-air dryer below $40^{\circ} \mathrm{C}$. The spherosomes showed little alteration even after 12 months of storage at $4^{\circ} \mathrm{C}$.

\section{$P L-D$ and $L O X$ activities}

PL-D and LOX are the lipid metabolizing enzymes that catalyze the degradation of phospholipids and unsaturated fatty acids, respectively. The occurrence of PL-D ${ }^{9)}$ and $\mathrm{LOX}^{11,12)}$ in rice grains was reported by several investigators. Table IV shows the activities of PL-D and LOX in the combined bran and embryo fraction, which was prepared from the grains just after drying under the various conditions. The initial activities of
Table IV. PL-D AND LOX ACTIVIties JUST AFTER DRYING

$$
\left(\times 10^{-3} \text { unit } / \mathrm{mg}\right)
$$

\begin{tabular}{lcccc}
\hline & \multicolumn{4}{c}{ Drying conditions } \\
\cline { 2 - 5 } Enzyme & Natural & $\begin{array}{c}30^{\circ} \mathrm{C} \\
\text { RH5\% }\end{array}$ & $\begin{array}{c}40^{\circ} \mathrm{C} \\
\text { RH5\% }\end{array}$ & $50^{\circ} \mathrm{C}$ \\
\hline PL-D & 454 & 481 & 513 & 523 \\
LOX & 140 & 154 & 150 & 146 \\
\hline
\end{tabular}

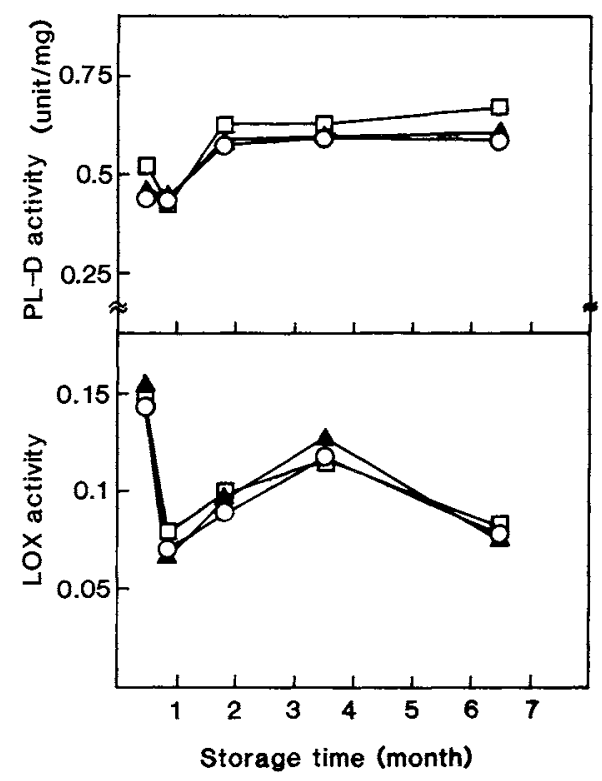

Fig. 5. Changes in the PL-D and LOX Activities during Storage.

After storage under various conditions, $50 \mathrm{~g}$ of husked rice was ground for $25 \mathrm{sec}$. The obtained embryo and bran (about $4 \mathrm{~g}$ ) were combined and macerated with a mortar and pestle for $5 \mathrm{~min}$. The enzymes were extracted with $50 \mathrm{~mm}$ Tris- $\mathrm{HCl}, \mathrm{pH} 7.0$, for $1 \mathrm{hr}$ at $4^{\circ} \mathrm{C}$. Then, PL-D and LOX activities were measured as described in Materials and Methods. - $\mathrm{O}-$, natural drying; $-\mathbf{A}-$, dehumidified-air drying $\left(30^{\circ} \mathrm{C}\right.$, RH $\left.5 \%\right) ;-\square-$, heated-air drying $\left(50^{\circ} \mathrm{C}\right)$.

LOX were not different among the three kinds of drying processes. On the other hand, the initial activities of PL-D in the dryings at $40^{\circ} \mathrm{C}$ ( $\mathrm{RH} 5 \%$ ) and $50^{\circ} \mathrm{C}$ were somewhat higher than those in the natural drying and dehumidified-air drying at $30^{\circ} \mathrm{C}$. Changes in the two enzyme activities during storage are shown in Fig. 5. From just after drying, both 
of the enzyme activities decreased in common with the three different drying methods and then increased in the next 1 or 2 months. PL$\mathrm{D}$ activities rose over the initial values and remained at high levels even after 6 months of storage, while LOX activities continued to increase for three months after storage through a drastic decrease after drying, although they did not reach the levels of inital activities, and decreased thereafter.

\section{Discussion}

As shown by several investigators, ${ }^{3.13 .14)}$ free fatty acids increased with a decrease in triacylglycerol at ambient temperature after 15 months storage of rice grains. However, the amount of free fatty acids did not increase very much during storage, although triacylglycerols markedly decreased. It indicates that the free fatty acids further decompose to low molecular weight components under these conditions, like volatile compounds. A similar phenomenon was observed in the change in phospholipid species. The conversion of $\mathrm{PC}$, LPC, and PE into PA occurred with the increase in the activity of PL-D after two months storage. PA was considered to be an intermediate in the degradation of phospholipids during storage of rice grains. Nakayama et al. ${ }^{15)}$ suggested that PL-D is important in the mechanism of lipid degradation during storage of soybean seeds.

The change in the phospholipid species of the grains after 15 months storage indicates that an alteration of the membrane constituents occurs in spherosomes, in which neutral lipids are accumulated. This change in the spherosome membrane seems to result in the degradation of the neutral lipids. In spite of the significant change in the phospholipid species of all of the dried grains, the grains dried at $50^{\circ} \mathrm{C}$ had the most drastic changes in the triacylglycerol content and the electron micrograph of spherosome particles. The decrease in PC and PE suggest that membranes broke down more rapidly in the grains from the heated-air drying. Furthermore, the kernel breakage ratio after heated-air drying at $50^{\circ} \mathrm{C}$ was much higher than that under the other drying conditions (Table I). This evidence suggests that the drying at $50^{\circ} \mathrm{C}$ caused undetectable changes in spherosomes, in addition to the breakdown of the phospholipid membrane, and these damages subsequently brought about more rapid decrease in neutral lipids, relative to the other drying conditions.

These data indicate the superiority of the dehumidified-air drying to the heated-air drying. Although the dehumidified-air drying took a longer time to dry the grains than the other conventional methods, the breakage ratio of the dried grains was low, and that was even without tempering. If the drying conditions are strictly selected, it is possible to shorten the drying time compared with the conventional methods that use tempering. Furthermore, this drying method prevent the grains from overheating compared with the heated-air drying. The dehumidified-air drying method is also available for the drying of other crops, such as wheat, which are harvested during the rainy season in Japan.

\section{References}

1) W. F. Geddes, Brewers Dig., 27, 89 (1952).

2) S. Aibara, H. Yamashita, I. A. Ismail, F. Sekiyama and Y. Morita, Agric. Biol. Chem., 48, 1293 (1984).

3) S. Aibara, I. A. Ismail, H. Yamashita, H. Ohta, F. Sekiyama and Y. Morita, Agric. Biol. Chem., 50, 665 (1986).

4) M. S. Buttrose and A. Soeffky, Aust. J. Biol. Sci, 26, 357 (1973).

5) D. B. Bechtel and Y. Pomeranz, Am. J. Bot., 65, 75 (1978).

6) D. B. Bechtel and Y. Pomeranz, Am.J. Bot., 65, 684 (1978).

7) K. Tanaka, M. Ogawa and Z. Kasai, Cereal Chem., 54, 684 (1977).

8) S. Imamura and Y. Horiuti, J. Biochem., 83, 677 (1978).

9) K. Takano, I. Kamoi and T. Obata, Nippon Shokuhin Kogyo Gakkaishi, 34, 8 (1987).

10) H. Ohta, S. Ida, B. Mikami and Y. Morita, Agric. Biol. Chem., 50, 3165 (1986).

11) A. Yamamoto, Y. Fujii, K. Yasumoto and H. Mitsuda, Agric. Biol. Chem., 44, 443 (1980).

12) S. Ida, Y. Masaki and Y. Morita, Agric. Biol. Chem., 47, 637 (1983). 
13) K. Yasumatsu and S. Moritaka, Agric. Biol. Chem., 28, 257 (1964).

14) M. G. Shin, S. H. Yoon, J. S. Rhee and T-W. Kwon,
J. Food Sci., 51, 460 (1986).

15) Y. Nakayama, K. Saio and M. Kito, Cereal Chem., 58, $260($ ( 981$)$. 